\title{
Should Large Spanish Municipalities Be Financially Compensated? Costs and Benefits of Being a Capital/Central Municipality*
}

\author{
NÚRIA BOSCH \\ MARTA ESPASA \\ DANIEL MONTOLIO \\ Barcelona Institute of Economics (IEB) \\ University of Barcelona
}

Received: February, 2014

Accepted: September, 2014

\begin{abstract}
Summary
We determine the costs and benefits of being a capital or central municipality, where central costs are understood to be incurred specifically as a result of the problems large municipalities located at the centre of an urban agglomeration face (including costs associated with social issues, immigration, commuting and diseconomies of scale) and capital costs result from the presence of regional and/or central government institutions in the municipality (loss of revenue or increase in expenditure because of activity substitution). However, these two qualities might also be beneficial to municipalities (resulting in a direct increase in their revenue or fiscal capacity). By estimating an equation of the expenditure needs and the fiscal capacity of Spanish municipalities with more than 75,000 inhabitants, we find that the central costs incurred by large municipalities are offset by their greater fiscal capacity, but that the same is not true for municipalities that serve as political/administrative capitals.
\end{abstract}

Keywords: Local financing, large municipalities, central and capital costs and benefits, expenditure needs, fiscal capacity.

JEL Classification: H72, H77, R51.

\section{Introduction}

Local public finances are currently under considerable stress and the financial crisis serves only to highlight the need to rethink both expenditure and revenue policies at all lev-

\footnotetext{
* We wish to thank participants at the XIX Encuentro de Economía Pública (University of Santiago de Compostela, 2012), the Jornada sobre Haciendas Locales (University of Zaragoza, 2012) and the $51^{\text {st }}$ Congress of the European Regional Science Association Conference (University of Barcelona, 2011) for insightful comments. The authors acknowledge support from grant 2009SGR102 (Generalitat de Catalunya) and from project ECO2012-37131 (Ministry of Economy and Competitiveness). Usual disclaimers apply.
} 
els of government. The situation is particularly critical among Spanish municipalities, which as the level of government closest to the citizens (voters) are responsible for delivering the most highly demanded public services, at a time when the Spanish financing system is failing to provide these authorities with adequate revenue tools to meet such demands ${ }^{1}$. The outlook is even worse for large municipalities, which are beset by a series of specific problems that have a direct impact on their local budget, but which are not contemplated by the local financing system. In the light of this current situation, the aim of this article is to estimate the impact on the expenditure needs and fiscal capacity of being a large capital or central municipality.

In terms of costs, the expenditure needs of large municipalities differ from those of other municipalities as their specific socioeconomic characteristics generate both central (spillover effects, concentration of social problems and/or congestion costs) and capital $\operatorname{costs}^{2}$ (including, the substitution of productive activities with less productive administrative activities or the loss of fiscal revenue because of the tax exemption of administrative activities).

Outside Spain, Washington D.C. is a good illustration of a city whose central and capital costs have not been solved by granting it a special financing system, but rather by increasing the percentage of financing of some of the federal transfer programmes and requiring the federal government to accept the provision of certain services (prisons and civil service pensions). A further illustration is provided by the case of the United Kingdom, where a system of unconditional transfers to municipalities, based on sophisticated methods of calculation, seeks to take into account certain factors related to central costs (McLean and McMillan, 2003; Midwinter, 2002).

In terms of revenue, the capital and/or central nature of a municipality may affect the decisions of individuals and firms when choosing where to locate in the territory and, therefore, have an impact on the size of the tax base for each municipality (fiscal capacity). According to Ladd and Bradbury (1988), the fiscal capacity of a sub-central government depends on the decisions adopted by individuals and enterprises, which in turn depend on the perceived costs and benefits from the localisation in the territory of this sub-central government.

The main contribution of this paper is to analyse the factors that affect large municipalities' expenditure needs and to determine whether these same factors also have a positive impact on their fiscal capacity. Specifically, we analyse the impact of being a capital or central municipality, factors which have not received much attention in the academic literature. However, Greene et al. (1974), Ladd and Yinger (1989), Chernick and Tkacheva (2002) do analyse whether commuter costs are offset by the revenues commuters generate, concluding that commuter costs (reflecting centrality) tend to be higher than any additional revenues. This paper provides further empirical evidence on this question, analysing from a wider perspective than that taken by these earlier studies (that is, by taking into account other factors in addition to commuting) whether the various costs borne by large municipalities are offset 
by the revenue generated by the economic activity, for instance, that the large municipalities can attract. To do so we draw on a dataset for Spanish municipalities with more than 75,000 inhabitants ${ }^{3}$, and estimate the determinants of both expenditure needs (Bosch and Solé-Ollé, 2005) and fiscal capacity. Note that, given that we focus on a certain type of municipalities (those with more than 75,000 inhabitants), we are studying the differential effects of some capital/central factors among those large municipalities; we do not analyse the impact of such factors with respect small size municipalities. This point is important to interpret and understand properly the results we obtain.

The present study comprises six sections, the first being this introduction. Section 2 describes the specific traits of large municipalities, in terms of their costs and revenues. Section 3 reports the empirical analysis and Section 4 describes the data used in the estimation of the equations of the expenditure needs and the fiscal capacity of large municipalities. Section 5 describes the main results obtained. Finally, section 6 concludes.

\section{The specific characteristics of large municipalities}

\subsection{Cost factors: central and capital costs}

\subsubsection{Central costs}

Central costs are those generated by the specific problems faced by large municipalities situated at the centre of an urban agglomeration. The main central cost is attributable to the flow of non-residents (those residing at a certain distance from the municipality in question) and which central cities absorb each day. Here, the main cost is caused by the spillover effect that municipal services are put under. Other central costs are attributable to the concentration of social problems (immigration, poverty, etc.) and those related to diseconomies of scale, density or congestion. Each of these costs is briefly described below.

\section{Spillover effects and congestion costs of municipal services}

A central municipality typically receives a large flow of non-residents: for reasons of work (commuters), education, shopping, administrative activities and leisure. These non-resident visitors use the services provided by the municipality for its inhabitants (and tax payers). The main costs for the municipality generated by non-residents can be identified as traffic management, cleaning, urban waste management, the maintenance of parks and public spaces as well as the provision of cultural and sports facilities and citizen safety and security. These services are provided by municipalities and (also) benefit non-residents that generally do not pay for them and, hence, they generate spillover (or external) effects and congestion costs.

For the Spanish case, the literature here is not very extensive and comprises basically the studies undertaken by Solé-Ollé $(2001,2006)$ and Bosch and Solé-Ollé (2005) examining the 
impact on the cost of the provision of municipal services of daily visitors who come to the central city for reasons of work and study. More specifically, Solé-Ollé (2001) quantifies the effects of a range of variables on the cost of providing municipal services in the municipalities of the Barcelona province with more than 5,000 inhabitants in 1996, concluding that commuters have an impact on expenditure on citizen safety and security, culture and sports, housing and urban development and public welfare. Solé-Ollé (2001) excludes, for reasons of comparability with the rest of the municipalities, the City of Barcelona; however, this inconvenience is solved in Bosch and Solé-Ollé (2005) and Solé-Ollé (2006) which draw on a sample of more than 3,000 Spanish municipalities with more than 1,000 inhabitants in the year 1999. In these studies the impact of non-residents on municipal public services is measured using the size of the population (i.e., potential non-resident users of the central city's public services) residing in locations within a 30-kilometre radius of the main central city. Solé-Ollé (2006) reports that a non-resident generates an average increase of $9.4 \%$ in the municipal expenditure generated by a resident, a figure that rises to $24 \%$ in the case of residents in municipalities located in large urban areas.

\section{Attractivity cost}

Another type of non-resident with quite specific characteristics is the tourist. Here the costs will be either direct (promotion paid for by the city council) or indirect (greater intensity of use of public services such as transport, cleaning, cultural activity and security).

\section{Cost of the concentration of social problems}

Central cities typically attract social problems associated with immigration, unemployment, poverty (the medium-high income population having abandoned the core areas) and delinquency. Solé-Ollé (2001) reports, for example, that rising poverty levels increase the cost of citizen safety and security, social services, culture and sports, and housing and urban development. Bosch and Solé-Ollé (2005) further report that immigrant population is potentially related with poverty and with a positive and statistically significant impact on municipal expenditure.

\section{Other cost factors}

The level of population has an impact on public service unit costs, either reducing (economies of scale) or raising them (costs of congestion). The costs of congestion can be related to the effects of commuting, as we have described above, and also to population density, which is normally higher in large municipalities. A high population density can, for example, increase the costs related to traffic, delinquency and the destruction of urban furniture. Likewise, in some cases, a low population density can also generate higher costs in the provision of public services, including refuse collection, public lighting or security (costs re- 
lated to disperse populations). For a detailed discussion of urban agglomerations seen from the perspective of public finance see Cadaval (2004).

\subsubsection{Capital costs}

Capital costs are related to the presence in the municipality of State and Autonomous Community government institutions. The main costs in this case can be grouped into two categories: i) loss of income due to activity substitution, and ii) an increase in expenditure due to activity substitution. Each of these factors is described briefly below.

\section{Loss of income due to activity substitution}

A municipality that serves as a political capital specialises in activities of an administrative nature and as a result the resources of the municipality (some of which are scarce, such as land) are used for administrative activities as opposed to other economic (primarily commerce and services) or residential activities. Activity substitution is not a neutral factor for the municipal treasury when the administrative activities of the Autonomous Communities and the State are exempt from payment of municipal taxes. So, for example, if a municipality contains the headquarters of government institutions it no longer receives the property tax corresponding to residences and/or businesses that hypothetically could occupy the area used for administrative purposes ${ }^{4}$. This argument can be extended to other taxes in the municipal domain, for example the Motor Vehicle Tax and some fees and public prices. Moreover, activity substitution with the increase of civil servants may lead to a lower average productivity in the municipality and, hence, weaken its fiscal bases.

\section{Increase in expenditure due to activity substitution}

It might also be the case that the substitution of residential, commercial and service activities with administrative activities generates an increase in municipal expenditure, for instance, in activities concerned with security and public safety (public events), in urban development and the maintenance of public spaces (parks and gardens) and the improvement and promotion of the image of the capital. These impacts are difficult to quantify although Bosch and Solé-Ollé (2005) propose a methodology that uses public sector employees (autonomous and central governments) per inhabitant as an approximation of municipal expenditure needs.

\subsection{Revenue factors: benefits from being a capital/central municipality}

The centrality or capital status of a large municipality can also potentially generate additional revenue. For instance, economies of agglomeration and infrastructures of communi- 
cation can attract the localisation of individuals and firms to large municipalities, and so have a positive effect on their fiscal capacity (Ladd and Bradbury, 1988). In this sense, Brueckner et al. (1999) report in a theoretical analysis conducted in Paris that individuals with higher levels of income tend to localise in zones with the best amenities (which in many cases are in, or close to, large urban areas).

Therefore, we also analyse the effect that all the aforementioned factors might have on the fiscal capacity of large municipalities. For instance, it is not clear whether the benefits of the economic activity generated by visitors (commuters or tourists) offset their costs (given the limited revenue instruments available to the municipalities). Empirical evidence from the United States seems to indicate that the costs derived from commuting are not recovered by such large cities as New York and Philadelphia (Chernik and Tkacheva, 2002). Greene et al. (1974) also evaluate the additional costs and revenues generated by non-residents for the US city of Washington.

Tourist enclaves exhibit many characteristics that are highly attractive to visitors and which can affect the fiscal capacity of the municipality through, for instance, a higher demand for housing. In such cases, real estate prices rise and, as a result, the value of the property tax base also rises. While only a few studies have sought to analyse whether tourism determines the tax base volume of a jurisdiction, Glaeser et al. (2001) are able to show that American cities with the highest amenity levels (variety of private services, adequate climatology, etc.) have higher housing prices, which in turn means a higher value of the property tax base. Likewise, Hawkins and Murray (2004) show that the number of hotels per capita, as a proxy of the number of visitors for leisure purposes, has a markedly positive effect on the per capita bases of a city's sales taxes.

In some ways, the previously presented costs could be seen as potential revenue raisers. Apart from the obvious cases of commuting (work, studies, shopping, administrative activities and leisure) and tourism, which are easily identified as potential sources of revenue for recipient municipalities via a variety of channels, other variables, including immigration, unit costs (wages) or activity substitution, could have a positive impact on a municipality's fiscal capacity. Indeed, all of them could attract more economic activity and, hence, increase directly and indirectly local revenues such as property tax or the tax on economic activities. Few studies to date have tested whether these factors also affect the fiscal capacity and, so, the analysis undertaken here also represents a new contribution to the testing of this relationship.

\section{Empirical analysis}

\subsection{Estimation of an equation of expenditure needs}

The quantification of expenditure needs is based on econometric estimations of the average estimated impact of the cost variables (both, central and capital) on municipal expen- 
diture per inhabitant ${ }^{5}$. In this way we can quantify the additional expenditure (measured with regard to the average) that these variables represent given the actual value that they take for each municipality under consideration (Solé-Ollé, 2001, 2006). In line with Bosch and SoléOllé (2005), the determinants of municipal expenditure can be expressed as:

$$
\ln (g / \text { op })=\alpha+\beta_{1} \ln (Z)+\beta_{2} \ln (F)+\beta_{3} \ln (X)+\varepsilon
$$

where $g / p o p$ is the per capita expenditure (current or total) ${ }^{6}, Z$ is a vector of cost variables, $F$ is a vector of fiscal variables that account for the resources available to the municipality, $X$ is a vector of other variables that are taken into account and $\varepsilon$ is the error term.

\subsection{Estimation of an index of fiscal capacity}

Estimating the impact of different variables on the fiscal capacity of a municipality requires that this index is first calculated. This is by no means straightforward as there is more than one way of calculating it, and there are various difficulties that must be overcome.

An index of fiscal capacity must capture as closely as possible the fiscal capacity of the municipality. In order to do this various methods have been proposed to measure the potential revenues of a municipality: $i$ ) tax collection; ii) macroeconomic indicators, including municipal GDP or municipal income; and iii) microeconomic indicators, including the Representative Tax System (RTS) ${ }^{7}$. More specifically, the RTS draws on the available information for the tax base $(B)$ of any type of municipal revenue and the standard tax rate $(t)$. With this information, and using the RTS approach, the index of fiscal capacity can be constructed as:

$$
\text { fiscal capacity }_{i}=\frac{\sum_{j=1}^{n} B_{i j} \times t_{j} / \text { Pop }_{i}}{\sum_{i=1}^{N} \sum_{j=1}^{n} B_{i j} \times t_{j} / \sum_{i=1}^{N} \operatorname{Pop}_{i}} i=1, \ldots, N \text { and } j=1, \ldots, n
$$

where $n$ is the number of different revenue sources considered and $N$ is the total number of municipalities considered. Eq. (2) can also be expressed as:

$$
\text { fiscal capacity }_{i}=\sum_{j=1}^{n} \alpha_{j} \frac{b_{i j}}{\bar{b}_{j}}
$$

where $\alpha_{j}$ is the share (summing up to 1) of each type of revenue in a representative budget and $b$ is the tax base expressed in per capita terms ${ }^{8}$. Given the budgetary structure of revenues for large municipalities, for our calculations we opt to use just the property tax and the tax on economic activity. In 2008 these local taxes represent $22.9 \%$ of current revenues and $66.7 \%$ of tax revenues ${ }^{9}$.

In the case of the property tax (the main source of municipal revenue), there is a major shortcoming to our obtaining a true measure of the fiscal capacity. The measure of the tax 
base is the cadastral value of the properties located in the municipality; however, the cadastral values are not homogenously updated for all municipalities. In other words, local governments can endogenously decide when to revise cadastral values and, hence, to increase (or otherwise) the tax base of the property tax ${ }^{10}$. There are two ways in which we can overcome this problem: by correcting the cadastral value or by implementing a correction via the tax rates. The first option is in practice particularly difficult to implement because we would require data on the evolution of the market prices of properties in all the municipalities and for all years or, alternatively, the evolution of data on housing prices (assuming that all properties evolve in a similar fashion to housing).

The second option is the correction of the tax base via tax rates based on the assumption that nominal tax rates differ between municipalities according to the time elapsed since the last updating of cadastral values. More specifically, we expect lower tax rates in those municipalities that have most recently revised their cadastral values ${ }^{11}$. Indeed, in the appendix we provide evidence supporting this assumption ${ }^{12}$. In practical terms, we use tax rate information to modify the property tax base: to each municipality $i$, and depending if it has revised cadastral values in 2001 or not, we apply the average tax rate of all those municipalities that have revised their cadastral values in the same period of time (before or after 2001).

In the case of the tax on economic activity, we use the municipal tax base (the so-called Cuotas minimas), which is the estimated contents of each business, professional and artistic activity weighted by coefficients depending on the location and turnover of the activities present in the municipality.

Therefore, we construct an index of fiscal capacity for large municipalities in Spain as presented in Eq. (3), with the shares $(\alpha)$ of the property tax and the tax on economic activity being equal to 84 and $16 \%$, respectively. Once the measure has been constructed we can then estimate its possible determinants in the same way as for the expenditure needs presented in Eq. (1).

$$
\ln \left(f_{c}\right)_{i}=\gamma+\partial_{1} \ln (F)+\partial_{2} \ln (S)+u
$$

where $f c$ is the index of fiscal capacity of municipality $i, F$ is a vector of fiscal variables, $S$ is a vector of economic and socio-demographic variables (some of which may coincide with the expenditure needs equation) and $u$ is the error term.

\subsection{Simultaneous determination of needs and capacity}

Finally, an important point to take into account to properly interpret the results obtained for the estimation of both the expenditure needs and the fiscal capacity equations, is that it might also be the case that the fiscal capacity determines the expenditure needs of a municipality or vice versa: i.e. a municipality might make its spending decisions in line with the fiscal capacity of its tax bases or (productive) expenditure might have a positive impact on 
the tax bases of the municipality and, hence, increase its fiscal capacity. Moreover, the aforementioned endogeneity problem might also be seen as simultaneous decisions being taken regarding property tax rate and fiscal capacity (and spending). In order to address this issue we estimate a simultaneous equation model using 3-SLS as follows:

$$
\begin{aligned}
& \ln (\text { g/pop })=\alpha+\beta_{1} \ln (Z)+\beta_{2} \ln (F)+\beta_{3} \ln (X)+\beta_{4} \ln (f c)+\varepsilon \\
& \ln (f c)=\gamma+\partial_{1} \ln (\text { prop_tax_08 })+\partial_{2} \ln (g / p o p)+\partial_{3} \ln (F)+\partial_{4} \ln (S)+u \\
& \ln (\text { prop_tax_08 })=\sigma+\lambda_{1} \ln (\text { prop_tax_07 })+\lambda_{2} \ln (f c)+\lambda_{3} \ln (g / p o p)+\lambda_{4} \ln (F)+v
\end{aligned}
$$

In Eq. (5) municipal expenditure per inhabitant ( $g / p o p)$, current and total, is both a dependent variable and enters as an explanatory variable of the fiscal capacity. Similarly, $f_{c}$ is also introduced as a determinant of expenditures needs. Finally, fiscal capacity and the property tax rate are also assumed to be decided simultaneously.

\section{Data issues}

\subsection{Variables and data used for the estimation of expenditure needs}

For the empirical estimation, all the municipalities that had over 75,000 inhabitants in 2008 are available, except Granada ${ }^{13}$; hence, we have information for 91 large municipalities in Spain. However, for reasons of data availability, we perform some of the estimations for a subsample of 86 municipalities, that is, excluding the municipalities of the Basque Country and Navarra. Table 1 presents summary statistics of all the variables used in the empirical estimations and which are described below.

\section{Dependent variable}

The econometric estimations take the current municipal expenditure per inhabitant ( $g c / p o p)$ as a dependent variable, as well as the total non-financial municipal expenditure per inhabitant (gt/pop). All municipal budgetary data come from the Spanish Ministry of Finance and Public Administration.

\section{Explanatory variables}

Spillover effects, congestion and attractivity costs (central costs)

We compute the population resident within a $30-\mathrm{km}$ radius of the municipality to proxy the potential spillover effect on its public services resulting from the (daily) use of non-resident visitors as well as the congestion costs derived from these potential commuters, as previously explained. The municipal population data are obtained from the Spanish National Statistics Institute (INE in its Spanish acronym) for the year $2008^{14}$. More specifically, the 
variable constructed (potential_users) is a measure of the potential users (population within $30-\mathrm{km}$ radius) in relation to the population of the central city interacted with a dummy variable that takes a value of 1 if the municipality is considered a central city and 0 if the municipality is peripheral and close to a central city ${ }^{15}$. By interacting potential users with this dummy variable means we only take into account those municipalities that have a power of attraction over their neighbouring municipalities.

To estimate the attractiveness cost on municipal expenditure of the number of tourists we use a municipal tourist index (i_tourism) calculated from the data provided by the "Spain Economic Yearbook" edited by La Caixa savings bank. The index is expressed as a percentage of the Spanish total and in relation to the resident population in the municipality (also expressed as a percentage of the Spanish total). This variable seeks to capture the intensive use of the resources of central municipalities that attract a large tourist population (because of such services as museums, cultural activities, beaches, etc.).

To approximate the congestion costs from commuters for consumption of private commercial services we use the employ_serv variable that represents the number of employees in the municipality working in the service sector in relation to the municipality's total population. This variable is created using data from the Institute of Economic Research of Valencia (IVIE in its Spanish acronym) and approximates the intensive use of the service sector in central municipalities that can attract the neighbouring population for consumer activities.

Table 1

DESCRIPTIVE STATISTICS

\begin{tabular}{|c|c|c|c|c|c|c|}
\hline Variable & Definition & Obs & Mean & Std. Dev. & Min & Max \\
\hline gt/pop & $\begin{array}{l}\text { Total non-financial expenditure } \\
\text { per inhabitant in } 2008\end{array}$ & 91 & 1049.83 & 318.55 & 625.08 & 3124.58 \\
\hline gc/pop & $\begin{array}{l}\text { Current expenditure per inhabitant } \\
\text { in } 2008\end{array}$ & 91 & 848.52 & 247.10 & 535.18 & 2473.45 \\
\hline potential_users & $\begin{array}{l}\text { Population within } 30 \mathrm{~km} \text { per inhabitant* } \\
\text { Dummy = } 1 \text { if central municipality in } 2008\end{array}$ & 91 & 1.09 & 1.47 & 0.00 & 6.78 \\
\hline i_tourism & $\begin{array}{l}\text { Touristic index (as a \% of Spanish total } \\
\text { index)/population (as a } \% \text { of Spanish } \\
\text { total population) in } 2007\end{array}$ & 91 & 0.93 & 1.64 & 0.01 & 11.37 \\
\hline employ_serv & $\begin{array}{l}\text { Employees in the service sector/ } \\
\text { population in } 2008\end{array}$ & 91 & 0.74 & 0.09 & 0.48 & 0.91 \\
\hline immg_non_eu & $\begin{array}{l}\text { Foreigners from outside the EU/ } \\
\text { population in } 2008\end{array}$ & 91 & 0.08 & 0.05 & 0.01 & 0.25 \\
\hline ипетр & Unemployment rate in 2008 & 91 & 5.6 & 1.88 & 2.4 & 10.6 \\
\hline$w_{-} \cos t$ & $\begin{array}{l}\text { Wage per worker paid in the local } \\
\text { administration in } 2006 \text { (index Spain =1) }\end{array}$ & 91 & 2.44 & 2.23 & 0.19 & 10.65 \\
\hline employ_public & $\begin{array}{l}\text { Employees of the central and autonomous } \\
\text { administration in } 2006 \text { / population }\end{array}$ & 91 & 0.023 & 0.021 & 0.003 & 0.108 \\
\hline
\end{tabular}


Table 1 (Continued)

DESCRIPTIVE STATISTICS

\begin{tabular}{llccccc}
\hline Variable & \multicolumn{1}{c}{ Definition } & Obs & Mean & Std. Dev. & Min & Max \\
\hline urban_area/pop & $\begin{array}{l}\text { Urban area }\left(\mathrm{km}^{2}\right) \text { in relation to the } \\
\text { population in 2008 }\end{array}$ & 86 & 0.014 & 0.011 & 0.002 & 0.073 \\
\hline pop_under_16 & $\begin{array}{l}\text { Population under 16 years of age/ } \\
\text { population in 2008 }\end{array}$ & 91 & 0.16 & 0.03 & 0.11 & 0.23 \\
\hline pop_over_65 & $\begin{array}{l}\text { Population over 65 years of age/ } \\
\text { population in 2008 }\end{array}$ & 91 & 0.15 & 0.04 & 0.06 & 0.22 \\
\hline pop_20_64 & $\begin{array}{l}\text { Population over 19 and under 65 years } \\
\text { of age/population in 2008 }\end{array}$ & 91 & 0.65 & 0.02 & 0.61 & 0.73 \\
\hline pop_illiterate & $\begin{array}{l}\text { Illiterate + population without schooling/ } \\
\text { population in 2001 }\end{array}$ & 91 & 0.13 & 0.05 & 0.02 & 0.27 \\
\hline pop_higher_educ & $\begin{array}{l}\text { Population with higher education/ } \\
\text { population in 2001 }\end{array}$ & 91 & 0.16 & 0.07 & 0.05 & 0.46 \\
\hline current_transf/pop & $\begin{array}{l}\text { Revenue from current transfers per } \\
\text { inhabitant in 2008 }\end{array}$ & 91 & 5.70 & 0.39 & 4.42 & 6.94 \\
\hline capital_transf/pop & $\begin{array}{l}\text { Revenue from capital transfers per } \\
\text { inhabitant in 2008 }\end{array}$ & 91 & 3.38 & 1.01 & 0.59 & 5.30 \\
\hline own_taxes/pop & $\begin{array}{l}\text { Revenue from own taxes per inhabitant } \\
\text { in 2008 }\end{array}$ & 91 & 5.81 & 0.28 & 4.59 & 6.67 \\
\hline fc & $\begin{array}{l}\text { Fiscal capacity index (index Spain }=1) \\
\text { in 2008 }\end{array}$ & 85 & 1.00 & 0.45 & 0.39 & 2.81 \\
\hline property_tax_08 & Property tax rate in 2008 & 85 & 0.68 & 0.18 & 0.38 & 1.17 \\
\hline property_tax_07 & Property tax rate in 2007 & 85 & 0.68 & 0.17 & 0.42 & 1.17 \\
\hline
\end{tabular}

\section{Concentration of social problems (central costs)}

The number of immigrants allows us to capture the influence of social factors on municipal expenditure. The data are obtained from the official register of residents published by the INE. Specifically, we use the percentage of foreign nationals from outside the EU in relation to the total population of the municipality (immg_non_eu). To account for other social factors we use the municipal unemployment rate in 2008 (unemp), which should also capture the level of economic activity in the municipality, and the illiterate population and the population without schooling in relation to the total population of the municipality (pop_illiterate).

\section{Costs of the factors (capital costs)}

The variation in public sector salary costs between municipalities is introduced as a capital cost. This variable, $w \_\operatorname{cost}^{16}$, is calculated as the total amount of wages in relation to the total number of workers in the local administration of the municipality ${ }^{17}$. Another variable, 
which likewise approximates the capital costs that a municipality incurs, is the number of workers employed in the central and autonomous administration (employ_public) that are present in the municipality. This variable is obtained by subtracting the number of workers in the local public administration (available from the official figures published by the Spanish Ministry of Public Administration - the Statistical Bulletin of Personnel Serving in the Public Administration) from the total number of workers in the municipality employed in the "public administration, defence and obligatory social security" (employment data taken from the two digit National Classification of Economic Activities published by IVIE). As with the other employment variables, they are calculated for the year $2006^{18}$.

\section{Other expenditure needs (control variables)}

In addition to the above variables that capture the features of the municipalities' capital and central statuses, we use other potential determinants of their expenditure needs as control variables. The urban area in relation to the population in 2008 (urban_area/pop) is taken into account to capture the effect of density on the cost of providing municipal services (for instance, refuse collection services). This variable is constructed with the area of buildings and building lots in each municipality (in square meters) in relation to its total population (data taken from the Cadastral Register).

Other variables included are those that refer to the characteristics of the municipal population that might have an impact on public expenditure: specifically, the population under 16 years of age in relation to the total population of the municipality (pop_under_16) ${ }^{19}$ and the population over 65 years of age in relation to the total population of the municipality (pop_over_65). These variables, calculated for the year 2008, measure the impact of the presence in the municipality of two groups of individuals who are likely to be the main receivers of municipal public services. Another control variable is the population with higher education in relation to the total population of the municipality (pop_higher_educ). In this case, people with higher education seem to tend to return to central municipalities, with the consequence of increases in the housing prices, and also higher demand for cultural services and leisure amenities from the municipality. In this way we are able to control the level of municipal expenditure in relation to the characteristics of the resident population, as these variables capture resident needs in a particular municipality as regards one level of expenditure or another. In this case, given that census data from the INE are required for their construction, the variables refer to values for the year 2001 .

\section{Availability of revenue}

The estimations of the equations for expenditure needs also require the use of variables associated with the revenues obtained by the municipality. The revenue from current transfers in relation to the population of the municipality in 2008 (current_transf/pop) is used in the regressions to quantify the resources received by the municipality from other levels of 
government ${ }^{20}$. We assume that the municipalities that receive most transfers can spend more. Likewise, income from capital transfers in relation to the population of the municipality for 2008 (capital_transf/pop) as well as the revenue from their own taxes per capita (own_taxes/pop) are calculated.

\subsection{Variables and data used for the estimation of fiscal capacity}

In general, the variables that might affect the fiscal capacity of a municipality are primarily fiscal variables and economic and socio-demographic variables. Below, we provide a detailed description of the variables included in the estimation of Eq. (4).

\section{Dependent variable}

The dependent variable is the fiscal capacity index $(f c)$ as described in detail in section 4.2 and in the appendix. We use data from the Cadastral Register which includes detailed information for all municipalities (except those in the Basque Country and Navarra). The urban land registry files include variables that accurately identify the municipality, province and $\mathrm{Au}$ tonomous Community to which the municipality belongs. They also include information for the year of the last cadastral revision, the number of urban units, the assessed value (in thousands of euros), the number of property tax receipts and taxable income (in thousands of euros). Finally, the dataset includes the tax rate applied by each municipality and the tax deductions.

\section{Explanatory variables}

\section{Fiscal variables}

In the short run, the main determinant of the fiscal capacity of a municipality is the tax rate on property, the main source of revenue for local governments with a fairly fixed tax base. Thus, as a determinant of fiscal capacity we include the property tax rate in the municipality in 2008 (property_tax_08). However, this rate is not exogenous to the fiscal capacity itself and, as a result, we might face problems of endogeneity. To overcome this problem we estimate the fiscal capacity equation using a 2-SLS procedure, using as instruments of the property tax rate in the municipality in 2008 the property tax rate in the previous year (property_tax_07) and the other sources of revenue current_transf/pop, capital_transf/pop and own_taxes/pop ${ }^{21}$.

\section{Economic and socio-demographic variables}

To analyse other possible determinants of the fiscal capacity of a given municipality, we adhere to a strategy founded on the fact that, a priori, many of the variables presented as 
costs factors might also well have a positive impact on a municipality's revenues. As discussed above, certain variables might also attract economic activity to the municipality, such as potential users (potential_users), tourists (i_tourism), a predominant presence of the service sector (employ_serv), immigration (immg_non_eu), higher wages ( $w_{-}$cost) or the presence of public servants from other administrations (employ_public).

Note that for some of the socio-demographic variables, we have no a priori expectations regarding their impact (if any) on the municipality's fiscal capacity. This is the case for those variables that refer to the characteristics of the municipal population (pop_under_16 and pop_over_65) ${ }^{22}$ and those that capture the educational level of the population (pop_illiterate and pop_higher_educ). In the case of unemployment (unemp), we expect a negative sign with respect to the fiscal capacity index, whereas we expect a positive impact of the variable capturing the urban surface area in relation to the population in 2008 (urban_area/pop).

\section{Main results}

The results of the estimation of the equation for expenditure needs are presented in Table 2 for the sample of 91 municipalities (columns 1 and 2) and for the sample of 85 municipalities with more than 75,000 inhabitants (columns 3 and 4). As discussed above, we do not have access to cadastral data for the municipalities of the Basque Country or those of Navarra and, hence, we are unable to use variables such as the urban surface area in relation to the population as a determinant of expenditure needs. The estimations have been carried out using two definitions of the dependent variable: current expenditure per capita and total nonfinancial expenditure per capita ${ }^{23}$.

Table 2

EXPENDITURE NEEDS IN MUNICIPALITIES WITH MORE THAN 75,000 INHABITANTS IN SPAIN. OLS ESTIMATES

\begin{tabular}{lcccc}
\hline \multirow{2}{*}{ Variables } & \multicolumn{2}{c}{ Full sample } & \multicolumn{2}{c}{$\begin{array}{c}\text { No Basque Country and Navarra } \\
\text { municipalities }\end{array}$} \\
\cline { 2 - 5 } & $\begin{array}{c}\text { Current needs } \\
\text { I_gc/pop }\end{array}$ & $\begin{array}{c}\text { Total needs } \\
\text { I_gt/pop }\end{array}$ & $\begin{array}{c}\text { Current needs } \\
\text { I_gc/pop }\end{array}$ & $\begin{array}{c}\text { Total needs } \\
\text { I_gt/pop }\end{array}$ \\
\hline potential_users & 0.007 & 0.010 & 0.006 & 0.012 \\
& $(0.012)$ & $(0.012)$ & $(0.012)$ & $(0.012)$ \\
1_i_tourism & $0.039^{* *}$ & $0.042^{* *}$ & $0.038^{* *}$ & $0.042^{* *}$ \\
& $(0.017)$ & $(0.016)$ & $(0.018)$ & $(0.017)$ \\
1_employ_serv & $0.439^{* *}$ & $0.433^{* *}$ & $0.615^{* * *}$ & $0.546^{* * *}$ \\
& $(0.189)$ & $(0.179)$ & $(0.207)$ & $(0.196)$ \\
1_immg_non_eu & -0.006 & 0.025 & 0.026 & 0.045 \\
& $(0.031)$ & $(0.029)$ & $(0.034)$ & $(0.032)$ \\
1_unemp & -0.084 & -0.113 & -0.033 & -0.081 \\
& $(0.100)$ & $(0.094)$ & $(0.106)$ & $(0.100)$ \\
\hline
\end{tabular}


Table 2 (Continued)

EXPENDITURE NEEDS IN MUNICIPALITIES WITH MORE THAN 75,000 INHABITANTS IN SPAIN. OLS ESTIMATES

\begin{tabular}{|c|c|c|c|c|}
\hline \multirow{2}{*}{ Variables } & \multicolumn{2}{|c|}{ Full sample } & \multicolumn{2}{|c|}{$\begin{array}{c}\text { No Basque Country and Navarra } \\
\text { municipalities }\end{array}$} \\
\hline & $\begin{array}{l}\text { Current needs } \\
\text { l_gc/pop }\end{array}$ & $\begin{array}{l}\text { Total needs } \\
\text { l_gt/pop }\end{array}$ & $\begin{array}{l}\text { Current needs } \\
\text { l_gc/pop }\end{array}$ & $\begin{array}{l}\text { Total needs } \\
\text { l_gt/pop }\end{array}$ \\
\hline 1_w_cost & $\begin{array}{c}0.254 * * * \\
(0.047)\end{array}$ & $\begin{array}{c}0.300 * * * \\
(0.045)\end{array}$ & $\begin{array}{l}0.296 * * * \\
(0.050)\end{array}$ & $\begin{array}{c}0.321 * * * \\
(0.047)\end{array}$ \\
\hline 1_employ_public & $\begin{array}{c}0.258 * * * \\
(0.052)\end{array}$ & $\begin{array}{c}0.286 * * * \\
(0.049)\end{array}$ & $\begin{array}{c}0.291 * * * \\
(0.055)\end{array}$ & $\begin{array}{l}0.292 * * * \\
(0.052)\end{array}$ \\
\hline 1_urban_area/pop & & $(0.040)$ & $\begin{array}{c}0.010 \\
(0.038)\end{array}$ & -0.023 \\
\hline 1_pop_under_16 & $\begin{array}{c}0.821 * * * \\
(0.183)\end{array}$ & $\begin{array}{c}0.799 * * * \\
(0.173)\end{array}$ & $\begin{array}{l}0.752 * * * \\
(0.196)\end{array}$ & $\begin{array}{c}0.791 * * * \\
(0.186)\end{array}$ \\
\hline 1_pop_over_65 & $\begin{array}{l}0.171^{*} \\
(0.095)\end{array}$ & $\begin{array}{l}0.160^{*} \\
(0.090)\end{array}$ & $\begin{array}{l}0.168^{*} \\
(0.096)\end{array}$ & $\begin{array}{l}0.158^{*} \\
(0.091)\end{array}$ \\
\hline 1_pop_higher_educ & $\begin{array}{c}-0.179 * * \\
(0.085)\end{array}$ & $\begin{array}{l}-0.103 \\
(0.081)\end{array}$ & $\begin{array}{l}-0.143 \\
(0.087)\end{array}$ & $\begin{array}{l}-0.066 \\
(0.083)\end{array}$ \\
\hline 1_pop_illiterate & $\begin{array}{l}-0.054 \\
(0.065)\end{array}$ & $\begin{array}{l}-0.058 \\
(0.061)\end{array}$ & $\begin{array}{l}0.001 \\
(0.075)\end{array}$ & $\begin{array}{l}-0.026 \\
(0.071)\end{array}$ \\
\hline 1_current_transf/pop & $\begin{array}{c}0.402 * * * \\
(0.050)\end{array}$ & $\begin{array}{c}0.407 * * * \\
(0.048)\end{array}$ & $\begin{array}{c}0.284 * * * \\
(0.071)\end{array}$ & $\begin{array}{l}0.296 * * * \\
(0.068)\end{array}$ \\
\hline 1_capital_transf/pop & $\begin{array}{l}-0.008 \\
(0.017)\end{array}$ & $\begin{array}{c}0.009 \\
(0.016)\end{array}$ & $\begin{array}{c}0.006 \\
(0.017)\end{array}$ & $\begin{array}{c}0.018 \\
(0.016)\end{array}$ \\
\hline 1_own_taxes/pop & $\begin{array}{c}0.111 \\
(0.086)\end{array}$ & $\begin{array}{l}-0.009 \\
(0.081)\end{array}$ & $\begin{array}{c}0.014 \\
(0.098)\end{array}$ & $\begin{array}{l}-0.132 \\
(0.093)\end{array}$ \\
\hline 1_fc & & $(0.058)$ & $\begin{array}{c}0.040 \\
(0.055)\end{array}$ & $0.096^{*}$ \\
\hline Constant & $\begin{array}{c}6.043 * * * \\
(0.831)\end{array}$ & $\begin{array}{c}7.037 * * * \\
(0.788)\end{array}$ & $\begin{array}{c}7.727 * * * \\
(0.985)\end{array}$ & $\begin{array}{c}8.563 * * * \\
(0.934)\end{array}$ \\
\hline Observations & 91 & 91 & 85 & 85 \\
\hline $\begin{array}{l}R \text {-squared } \\
F\end{array}$ & $\begin{array}{c}0.67 \\
10.82 * * *\end{array}$ & $\begin{array}{c}0.73 \\
14.71 * * *\end{array}$ & $\begin{array}{c}0.67 \\
8.73^{* * *}\end{array}$ & $\begin{array}{c}0.74 \\
11.96^{* * *}\end{array}$ \\
\hline
\end{tabular}

Note: Standard errors in parentheses $* * * \mathrm{p}<0.01, * * \mathrm{p}<0.05, * \mathrm{p}<0.10$. We obtain robust estimates eliminating Barcelona and Madrid from the sample and using an index of fiscal capacity, as explanatory variable, based only in the property tax.

The results in Table 2 indicate that, in the case of factors related to central costs (i.e., spillover effects), the number of tourists and the number of employees in the service sector are positive, statistically significant determinants. Moreover, given that these variables are introduced in log format, they can be interpreted as elasticities. Hence, a one per cent increase in the tourist index increases total non-financial expenditure per capita by $0.042 \%$, while a one percent increase in the share of employees engaged in the service sector increas- 
es total non-financial expenditure per capita between 0.43 and $0.54 \%$. By contrast, the potential number of users of the municipality's public services (measured in terms of the population resident within a $30 \mathrm{~km}$ radius of the central city in relation to the total population of the city interacted with a dummy variable indicating the municipality's central status) is not statistically significant. The fact that this factor is not statistically significant is somehow expected given that, as previously pointed out, we do not analyze differential costs of large municipalities in front of small municipalities. We study the effect of some factors across central and capital municipalities, all of them above 75,000 inhabitants. Therefore, it seems that commuters are not a factor that differentiates the cost among those cities. Most probably, and as pointed out in Solé-Ollé (2001), commuters are a differential cost with respect small municipalities, but we are not analyzing that effect. Similarly, immigration and unemployment variables do not seem to be significant determinants of expenditure needs either across large municipalities.

As for the factors representing capital costs, the two variables tested were found to be positive and statistically significant factors with an estimated impact of around $0.30 \%$. These results indicate that the number of workers employed by the central and autonomous administrations located in the municipality, in addition to the salaries paid to the employees of the local administration, have a positive impact on municipal expenditure.

The results obtained for the variables capturing the municipalities' expenditure needs, including the share of population under 16 , are statistically significant and positive with a very high estimated elasticity $(0.8 \%)^{24}$. Similarly, the share of population over 65 is also positive, but this factor presents a lower level of significance and a lower point estimate $(0.16 \%)$. Both variables reflecting the educational level of the population and the population density variable were found not to be statistically significant. In the case of the fiscal variables, the estimations conducted confirm that only revenue derived from current transfers has a positive impact on expenditure needs. Note that these results are fairly robust according to the four models analysed (two dependent variables and two samples) and do not present significant differences across the estimated models.

The results of the estimation of the equation for fiscal capacity using instrumental variables are shown in Table 3. First, the Sargan test reported at the bottom of Table 3 determines the validity of the instruments used. Second, as expected, the property tax rate has a negative impact on the fiscal capacity index (equal, remember, to 0.84 and $0.16 \%$ of the tax bases of the property tax and the tax on economic activity, respectively). Third, in the case of the impact of the variables that account for the centrality costs of municipalities we find, in line with the expenditure needs estimation, that the variables capturing the number of potential users and the level of immigration in the municipality are not statistically significant, whereas tourism and the number of employees in the service sector are positive and significant determinants of the fiscal capacity index of the municipality. Moreover, unemployment is found to be significant and to present a negative sign; that is, the higher the level of unemployment in the municipality, the lower is its fiscal capacity - a result that, in principle, makes economic sense. 
Table 3

FISCAL CAPACITY IN MUNICIPALITIES WITH MORE THAN 75,000 INHABITANTS IN SPAIN (EXCLUDING MUNICIPALITIES IN THE BASQUE COUNTRY AND NAVARRA). INSTRUMENTAL VARIABLE ESTIMATES USING 2-SLS

\begin{tabular}{|c|c|c|c|c|}
\hline Variables & l_fc & I_fc & l_fc & l_fc \\
\hline \multirow[t]{2}{*}{ 1_property_tax_08 } & $-0.260 *$ & $-0.269 *$ & $-0.296 * *$ & $-0.363 * *$ \\
\hline & $(0.148)$ & $(0.143)$ & $(0.142)$ & $(0.144)$ \\
\hline \multirow[t]{2}{*}{ potential_users } & 0.010 & 0.014 & 0.015 & 0.021 \\
\hline & $(0.025)$ & $(0.024)$ & $(0.024)$ & $(0.025)$ \\
\hline \multirow[t]{2}{*}{ 1_i_tourism } & $0.058^{*}$ & $0.059^{*}$ & $0.064 * *$ & $0.096 * * *$ \\
\hline & $(0.035)$ & $(0.033)$ & $(0.032)$ & $(0.031)$ \\
\hline \multirow[t]{2}{*}{ 1_employ_serv } & 0.658 & $0.704 *$ & $0.825 * *$ & 0.429 \\
\hline & $(0.418)$ & $(0.422)$ & $(0.394)$ & $(0.379)$ \\
\hline \multirow[t]{2}{*}{ 1_immg_non_eu } & -0.006 & -0.003 & 0.014 & -0.011 \\
\hline & $(0.068)$ & $(0.067)$ & $(0.063)$ & $(0.065)$ \\
\hline \multirow[t]{2}{*}{ 1_unemp } & -0.296 & $-0.327 *$ & $-0.317 *$ & $-0.384 * *$ \\
\hline & (0.199) & $(0.189)$ & $(0.189)$ & $(0.194)$ \\
\hline \multirow[t]{2}{*}{ 1_W_cost } & 0.123 & 0.116 & $0.171^{*}$ & $0.203 * *$ \\
\hline & $(0.121)$ & $(0.119)$ & $(0.098)$ & $(0.101)$ \\
\hline \multirow[t]{2}{*}{ 1_employ_public } & 0.046 & 0.043 & 0.091 & 0.106 \\
\hline & $(0.128)$ & $(0.124)$ & $(0.109)$ & $(0.113)$ \\
\hline \multirow[t]{2}{*}{ 1_urban_area/pop } & $0.184^{* *}$ & $0.172 * * *$ & $0.168 * * *$ & \\
\hline & $(0.078)$ & $(0.062)$ & $(0.062)$ & \\
\hline \multirow[t]{2}{*}{ 1_pop_under_16 } & 0.316 & & & \\
\hline & $(0.444)$ & & & \\
\hline \multirow[t]{2}{*}{ 1_pop_over_65 } & 0.304 & & & \\
\hline & $(0.198)$ & & & \\
\hline \multirow[t]{2}{*}{ 1_pop_20_64 } & & -1.347 & -1.520 & $-1.869 *$ \\
\hline & $(1.082)$ & (1.066) & (1.098) & \\
\hline \multirow[t]{2}{*}{ 1_pop_higher_educ } & -0.019 & -0.006 & 0.003 & 0.090 \\
\hline & $(0.171)$ & $(0.163)$ & $(0.163)$ & $(0.166)$ \\
\hline \multirow[t]{2}{*}{ 1_pop_illiterate } & 0.100 & 0.127 & 0.155 & 0.209 \\
\hline & $(0.138)$ & $(0.134)$ & $(0.129)$ & $(0.132)$ \\
\hline \multirow[t]{2}{*}{ 1_gt/pop } & 0.185 & 0.156 & & \\
\hline & $(0.211)$ & $(0.195)$ & & \\
\hline \multirow[t]{2}{*}{ Constant } & 0.194 & -1.412 & -0.078 & -1.038 \\
\hline & $(2.367)$ & $(2.008)$ & (1.105) & $(1.085)$ \\
\hline Observations & 85 & 85 & 85 & 85 \\
\hline$R$-squared & 0.45 & 0.44 & 0.44 & 0.40 \\
\hline Sargan & $29.03 * * *$ & $29.04 * * *$ & $27.67 * * *$ & $31.08 * * *$ \\
\hline
\end{tabular}

Note: Standard errors in parentheses $* * * \mathrm{p}<0.01, * * \mathrm{p}<0.05, * \mathrm{p}<0.10$. We obtain robust estimates eliminating Barcelona and Madrid from the sample, using current expenditure per capita as explanatory variable instead of total expenditure per capita and using as a dependent variable an index of fiscal capacity based only in the property tax. 
Fourth, an inspection of the variables that capture a municipality's capital status shows that the results are not as significant as they are in the expenditure needs equation. Here, only the variable that approximates the salaries paid to employees in the local public sector is positive and slightly significant (0.17-0.20\%). Fifth, as regards our findings for the other potential determinants of a municipality's fiscal capacity (in the main, the socio-demographic variables), the most notable result is the positive and very significant impact of population density (which presumably captures the positive impact on the tax base of the property tax) and the fact that, in general, the variables capturing the age structure and the level of education of the population do not have a significant effect on the fiscal capacity index.

Finally, and given the (more than) likely simultaneity of expenditure needs, fiscal capacity and property tax, we estimate the three equations simultaneously by means of 3-SLS (see, Eq. 5) to confirm, or not, the results obtained up to this juncture. The results, reported in Table 4, confirm our previous findings. Note that the results suggest a clear simultaneity between fiscal capacity and property tax rate, but this is by no means so clear when analysing needs and fiscal capacity. In the latter case, note that the fiscal capacity index is not a significant determinant of expenditure needs and, likewise, the current (or total non-financial) expenditure per capita does not seem to affect the fiscal capacity index. Therefore, the results presented above can be considered valid, particularly given that the results for the fiscal capacity index (Table 4) were obtained by introducing the property tax rate as an explanatory variable and using 2-SLS to instrument the possible endogenous determination of tax rates and tax bases, especially in the case of the property tax.

Table 4

JOINT DETERMINATION OF EXPENDITURE NEEDS, FISCAL CAPACITY AND PROPERTY TAX RATE USING 3-SLS

\begin{tabular}{|c|c|c|c|c|c|c|}
\hline Variables & $\begin{array}{c}\text { Current } \\
\text { needs } \\
\text { 1_gc/pop }\end{array}$ & $\begin{array}{c}\text { Fiscal } \\
\text { capacity } \\
\text { I_fc }\end{array}$ & $\begin{array}{c}\text { Property } \\
\text { tax rate } \\
\text { I_prop_tax }\end{array}$ & $\begin{array}{c}\text { Total } \\
\text { needs } \\
\text { I_gt/pop }\end{array}$ & $\begin{array}{c}\text { Fiscal } \\
\text { capacity } \\
\text { I_fc }\end{array}$ & $\begin{array}{c}\text { Property } \\
\text { tax rate } \\
\text { l_prop_tax }\end{array}$ \\
\hline \multirow[t]{2}{*}{ potential_users } & 0.007 & 0.022 & & 0.014 & 0.029 & \\
\hline & $(0.012)$ & $(0.022)$ & & $(0.011)$ & $(0.024)$ & \\
\hline \multirow[t]{2}{*}{ 1_i_tourism } & $0.042 * *$ & 0.047 & & $0.044 * * *$ & $0.063^{*}$ & \\
\hline & $(0.017)$ & $(0.037)$ & & $(0.015)$ & $(0.038)$ & \\
\hline \multirow[t]{2}{*}{ 1_employ_serv } & $0.795 * * *$ & $1.059 * *$ & & $0.568 * * *$ & $1.162 * *$ & \\
\hline & $(0.195)$ & $(0.480)$ & & $(0.180)$ & $(0.454)$ & \\
\hline \multirow[t]{2}{*}{ 1_immg_non_eu } & 0.022 & -0.019 & & 0.045 & -0.003 & \\
\hline & $(0.031)$ & $(0.062)$ & & $(0.029)$ & $(0.067)$ & \\
\hline \multirow[t]{2}{*}{ 1_unemp } & -0.101 & $-0.425^{* *}$ & & -0.101 & $-0.450 * *$ & \\
\hline & $(0.097)$ & $(0.181)$ & & $(0.090)$ & $(0.191)$ & \\
\hline \multirow[t]{2}{*}{ 1_w_cost } & $0.332 * * *$ & 0.220 & & $0.320 * * *$ & $0.306^{*}$ & \\
\hline & $(0.049)$ & $(0.158)$ & & $(0.045)$ & $(0.164)$ & \\
\hline \multirow[t]{2}{*}{ 1_employ_public } & $0.310 * * *$ & 0.118 & & $0.287 * * *$ & 0.188 & \\
\hline & $(0.053)$ & $(0.163)$ & & $(0.048)$ & $(0.163)$ & \\
\hline
\end{tabular}


Table 4 (Continued)

JOINT DETERMINATION OF EXPENDITURE NEEDS, FISCAL CAPACITY AND PROPERTY TAX RATE USING 3-SLS

\begin{tabular}{|c|c|c|c|c|c|c|}
\hline Variables & $\begin{array}{c}\text { Current } \\
\text { needs } \\
\text { l_gc/pop }\end{array}$ & $\begin{array}{c}\text { Fiscal } \\
\text { capacity } \\
\text { I_fc }\end{array}$ & $\begin{array}{l}\text { Property } \\
\text { tax rate } \\
\text { l_prop_tax }\end{array}$ & $\begin{array}{c}\text { Total } \\
\text { needs } \\
\text { I_gt/pop }\end{array}$ & $\begin{array}{c}\text { Fiscal } \\
\text { capacity } \\
\text { I_fc }\end{array}$ & $\begin{array}{l}\text { Property } \\
\text { tax rate } \\
\text { l_prop_tax }\end{array}$ \\
\hline 1_urban_area/pop & $\begin{array}{c}0.051 \\
(0.044)\end{array}$ & $\begin{array}{c}0.144 * * \\
(0.071)\end{array}$ & & $\begin{array}{l}-0.028 \\
(0.041)\end{array}$ & $\begin{array}{c}0.105 \\
(0.084)\end{array}$ & \\
\hline 1_pop_under_16 & $\begin{array}{c}0.812 * * * \\
(0.181)\end{array}$ & $\begin{array}{c}0.722 \\
(0.478)\end{array}$ & & $\begin{array}{c}0.807 * * * \\
(0.167)\end{array}$ & $\begin{array}{l}0.980^{*} \\
(0.524)\end{array}$ & \\
\hline 1_pop_over_65 & $\begin{array}{l}0.201 * * \\
(0.091)\end{array}$ & $\begin{array}{c}0.291 \\
(0.189)\end{array}$ & & $\begin{array}{l}0.156^{*} \\
(0.083)\end{array}$ & $\begin{array}{l}0.377 * \\
(0.202)\end{array}$ & \\
\hline 1_pop_higher_educ & $\begin{array}{c}-0.161 * * \\
(0.081)\end{array}$ & $\begin{array}{l}-0.110 \\
(0.160)\end{array}$ & & $\begin{array}{l}-0.065 \\
(0.074)\end{array}$ & $\begin{array}{l}-0.086 \\
(0.163)\end{array}$ & \\
\hline 1_pop_illiterate & $\begin{array}{c}0.021 \\
(0.069)\end{array}$ & $\begin{array}{c}0.158 \\
(0.132)\end{array}$ & & $\begin{array}{l}-0.018 \\
(0.064)\end{array}$ & $\begin{array}{c}0.180 \\
(0.135)\end{array}$ & \\
\hline 1_current_transf/pop & $\begin{array}{c}0.302 * * * \\
(0.072)\end{array}$ & & $\begin{array}{c}-0.064 * \\
(0.034)\end{array}$ & $\begin{array}{c}0.280 * * * \\
(0.066)\end{array}$ & & $\begin{array}{c}-0.058^{*} \\
(0.032)\end{array}$ \\
\hline 1_capital_transf/pop & $\begin{array}{c}0.009 \\
(0.016)\end{array}$ & & $\begin{array}{l}-0.005 \\
(0.008)\end{array}$ & $\begin{array}{c}0.016 \\
(0.015)\end{array}$ & & $\begin{array}{l}-0.008 \\
(0.008)\end{array}$ \\
\hline 1_own_taxes/pop & $\begin{array}{c}0.043 \\
(0.130)\end{array}$ & & $\begin{array}{c}0.139 \\
(0.093)\end{array}$ & $\begin{array}{l}-0.184 \\
(0.120)\end{array}$ & & $\begin{array}{c}0.117 \\
(0.087)\end{array}$ \\
\hline 1_fc & $\begin{array}{l}-0.158 \\
(0.134)\end{array}$ & & $\begin{array}{c}-0.317 * * * \\
(0.095)\end{array}$ & $\begin{array}{c}0.119 \\
(0.123)\end{array}$ & & $\begin{array}{c}-0.268 * * * \\
(0.086)\end{array}$ \\
\hline 1_property_tax_08 & $(0.143)$ & $-0.336 * *$ & & (0.168) & $-0.411 * *$ & \\
\hline 1_gc/pop & $(0.427)$ & $\begin{array}{l}-0.081 \\
(0.064)\end{array}$ & $0.229 * * *$ & & & \\
\hline 1_property_tax_07 & & $(0.061)$ & $0.834 * * *$ & & $(0.054)$ & $0.880 * * *$ \\
\hline 1_gt/pop & & & & $(0.401)$ & $\begin{array}{l}-0.359 \\
(0.053)\end{array}$ & $0.170 * * *$ \\
\hline Constant & $\begin{array}{c}7.699 * * * \\
(1.057)\end{array}$ & $\begin{array}{c}2.410 \\
(4.129)\end{array}$ & $\begin{array}{c}-2.058 * * * \\
(0.796)\end{array}$ & $\begin{array}{c}8.918 * * * \\
(0.974)\end{array}$ & $\begin{array}{c}5.137 \\
(4.050)\end{array}$ & $\begin{array}{c}-1.577 * * \\
(0.699)\end{array}$ \\
\hline Observations & 85 & 85 & 85 & 85 & 85 & 85 \\
\hline $\begin{array}{l}R \text {-squared } \\
\text { chi2_l }\end{array}$ & $\begin{array}{c}0.61 \\
163.33^{* * *}\end{array}$ & 0.42 & 0.90 & $\begin{array}{c}0.74 \\
235.52 * * *\end{array}$ & 0.39 & 0.91 \\
\hline $\begin{array}{l}\text { chi2_2 } \\
\text { chi2_3 }\end{array}$ & & $66.80 * * *$ & $875.89 * * *$ & & $64.59 * * *$ & $952.54 * * *$ \\
\hline
\end{tabular}

Note: Standard errors in parentheses $* * * \mathrm{p}<0.01, * * \mathrm{p}<0.05, * \mathrm{p}<0.10$. We obtain robust estimates eliminating Barcelona and Madrid from the sample and using as a dependent variable an index of fiscal capacity based only in the property tax. 
In short, the results in Table 4 show that the centrality variables of tourism and employment in the service sector affect both expenditure needs and fiscal capacity. At the same time, the number of potential users and immigration are not significant factors, although the unemployment rate does have a negative impact on the fiscal capacity of municipalities. The capital status variables seem to have a greater impact on expenditure needs than they do on fiscal capacity, a finding that is similar for the socio-demographic variables which, as expected, seem to have a greater effect on expenditure needs.

\section{Conclusions}

This study has determined the costs and benefits for Spain's large municipalities (defined as those with a population over 75,000 inhabitants) of being a capital or central municipality. We bring a series of rigorously tested results to what remains an on-going and highly ideological debate in Spain regarding the financing of local governments, and especially the governments of large municipalities. While it is indisputable that these municipalities face higher costs given their particular nature, it is equally true that they also obtain additional economic benefits that need to be evaluated with these costs to obtain a complete picture of the public finances of these governments, especially if these questions are to be taken into account in possible reforms of the local financing system.

Our results indicate that there are indeed significant costs factors associated with the central/capital nature of a municipality that influence the local per capita expenditure of these municipalities. These factors are essentially related to the existence of spillover effects (central costs) in central cities, measured by the number of tourists and the weight of the service sector, and the existence of capital costs associated with the amount of employment in other levels of government and the salaries paid in the local public sector. Our results also show that the socioeconomic structure can influence expenditure needs (primarily, the share of the population under 16 and over 65). Interestingly, we also find that the variables capturing the central status of municipalities result in an increase in their fiscal capacity, but the variables capturing their status as a capital do not seem to be determinants of this fiscal capacity.

Thus, the main conclusion to be drawn from this study is that the centrality characteristics of large municipalities in Spain increase their expenditure needs; yet, they have a positive impact on their fiscal capacity. As such, centrality implies certain additional costs, but it also brings some benefits. By contrast, the capital status of a municipality seems to generate mainly costs; that is, being a capital increases expenditure needs. Consequently, the local financing system for the large municipalities in Spain needs to give greater consideration to factors linked to capital characteristics, since the factors associated with the centrality characteristics of municipalities appear to be offset by their greater fiscal capacity and, hence, do not, in principle, need to be explicitly recognised by the financing system. 


\section{Appendix: Calculation for the index of fiscal capacity}

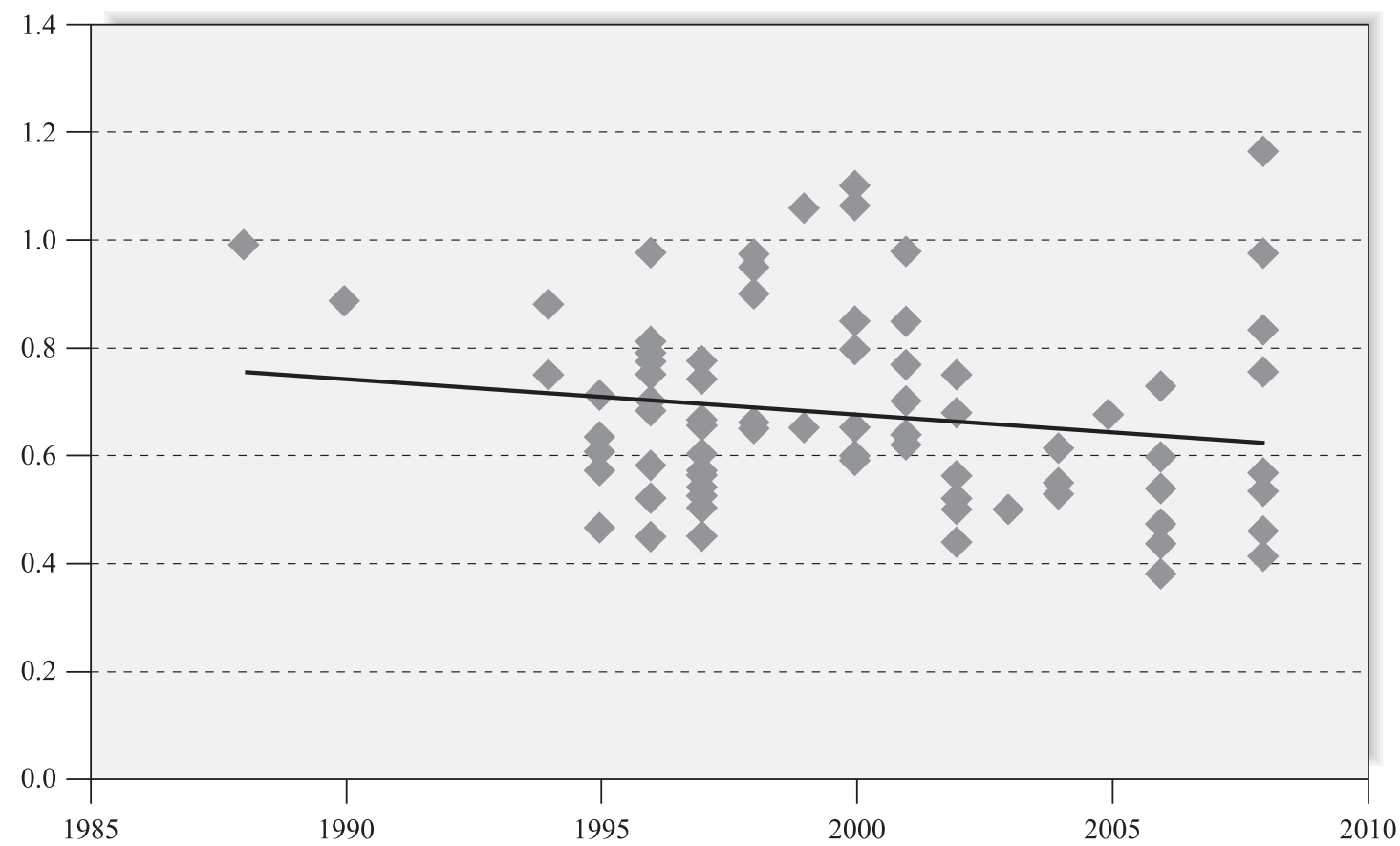

Figure A.1. Property tax (vertical axis) and last year of cadastral revision (horizontal axis)

Kernel density estimate

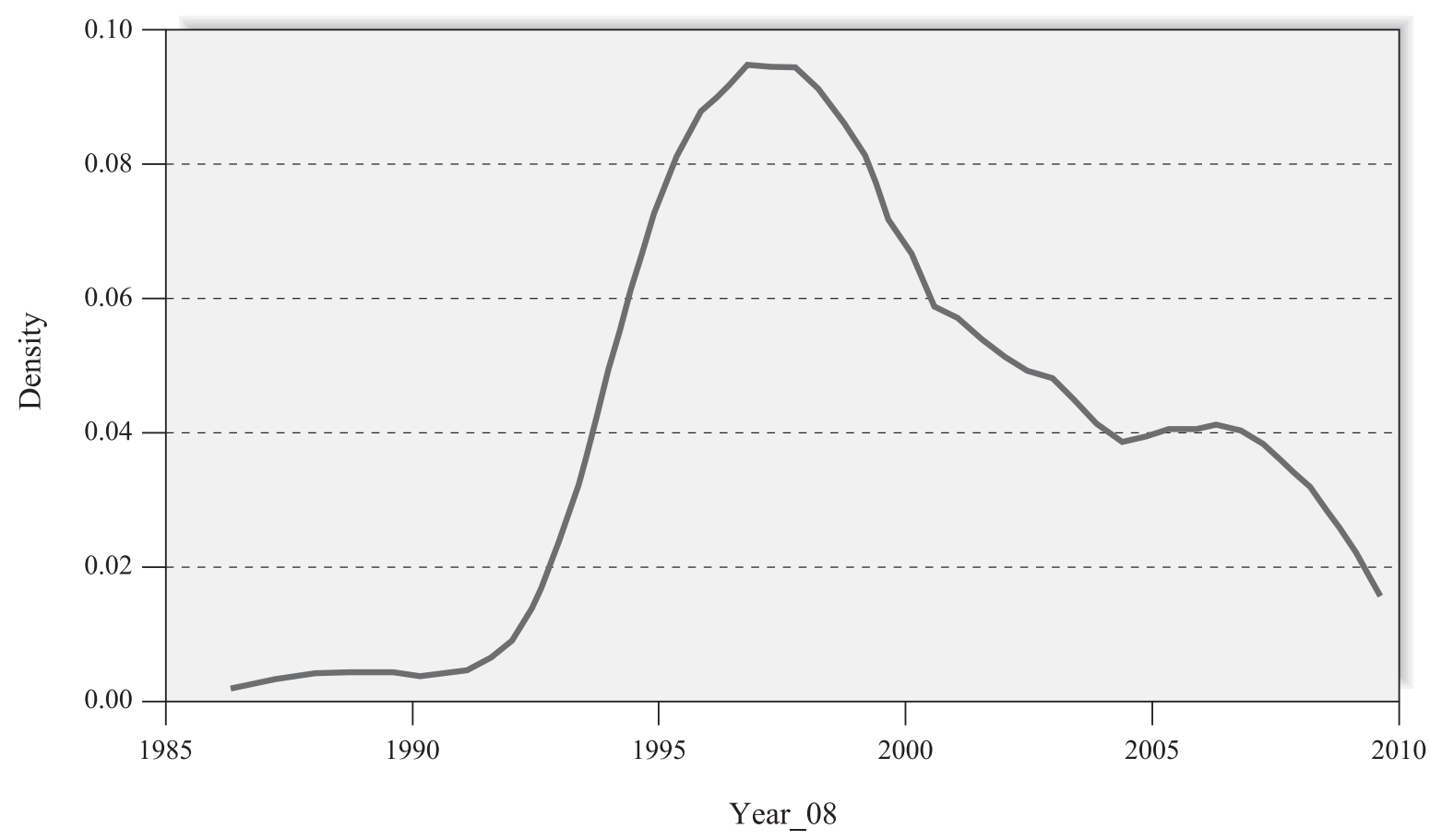

Figure A.2. Distribution of municipalities depending on the last year of cadastral revision Kernel $=$ epanechnikov, bandwidth $=1.6463$ 
Table A.1.

CORRECTION OF THE TAX BASE OF THE PROPERTY TAX

\begin{tabular}{|c|c|}
\hline Variables & Property tax rate \\
\hline Discontinuity & $\begin{array}{c}0.2643 \\
(0.002) * * *\end{array}$ \\
\hline Time & $\begin{array}{c}-0.0474 \\
(0.008)^{* * *}\end{array}$ \\
\hline$(\text { Time })^{\wedge} 2$ & $\begin{array}{c}0.002 \\
(0.016)^{* *}\end{array}$ \\
\hline Constant & $\begin{array}{c}0.7121 \\
(0.000)^{* * *}\end{array}$ \\
\hline Observations & 85 \\
\hline$R$-squared & 0.1565 \\
\hline$F(3,81)$ & $5.01 * * *$ \\
\hline
\end{tabular}

Note: Robust standard errors in parentheses $* * * \mathrm{p}<0.01, * * \mathrm{p}<0.05, * \mathrm{p}<0.1 . p$-values in brackets. Discontinuity $=1$ if year is previous to 2001 .

\section{Notes}

1. The Spanish Law on Local Authorities draws a distinction between municipalities on the basis of population size; however, this distinction differs according to the specific area being regulated (organizational, competences or financing). Referring to competences Article 26 of this Law lists the minimum competences that can be required to all municipalities (compulsory competences). These are public lighting, cemeteries, waste collection, street cleaning, the domestic supply of drinking water, drains and sewers, access roads to centres of population, paving of public roads and control of food and beverages. The same Law divides municipalities into population ranges, the highest of which is municipalities with a population over 50,000 inhabitants and, based on those ranges, municipalities are designated additional competences. These are the so-called delegated competences. Moreover, the municipalities can also provide other additional services if they decide to do it (discretional competences). As for financing, the same model is applied to all the municipalities, with some adjustments being made according to population size and delegated competences, affecting above all tax rates and unconditional transfers. Nevertheless, the assignment of delegated responsibilities is not properly covered by adequate concomitant resources. The municipalities do not receive specific resources for the additional/discretional competences provided to citizens.

2. Throughout the paper we use, for our convenience, the term "capital cost" as a synonym of "costs of being a capital",

3. The Spanish legislation does not provide a single definition as to what constitutes a large municipality (or city), although being an institutional capital is recognised as a distinctive feature to be taken into account. We take as our definition of large municipalities those with a population over 75,000 inhabitants, that is, adopting the categorisation used in the State's financing system.

4. This argument remains valid as long as the urban land available is fixed and its occupation by the administration tends to drive other economic activities outside the municipal area.

5. Similar studies that estimate expenditure needs are, for instance, Allers and Ishemoi (2011) for Tanzania; Ball et al. (2012) for health care spending needs of the UK; Bailey (2005) for England, King et al. (2004) for Scotland.

6. The measure of expenditure used is the current expenditure per capita. Nevertheless, for reasons of the robustness of the estimation the total expenditure per capita is also used. 
7. The Representative Revenue System (RSS) might also be used when the revenues based on the benefit principle are also included in the fiscal capacity index. However, we opted not to include these revenues (user fees and public prices) in our calculations given that they are endogenous to political decisions, at least, more so than the other sources of revenue used.

8. The advantage of this formulation is that it avoids our having to calculate the standard tax rate.

9. On average, in 2008 , the municipal non-financial revenue for large municipalities comes basically from grants $(36.9 \%)$ and local taxes (34.5\%). Moreover, there are also fees, sales, and fines (17.2\%), property income $(6.6 \%)$ and tax shares on national taxes $(4.8 \%)$.

10. In this sense, uncorrected tax bases (those in the municipalities that have not updated their cadastral values) would present a lower capacity index because of a political decision, and one moreover that does not reflect the reality of the municipality, that is, its true potential fiscal capacity through, for example, its actual housing values.

11. The effective tax burden on a municipality is obtained by combining both the nominal tax rate and the extent to which the tax base (cadastral value) resembles the market price of the cadastral unit. Thus, given a municipality's revenue target, and in the absence of the corresponding revaluation of cadastral value, we would expect a higher nominal rate in those municipalities with cadastral values that have not been revised for some time.

12 In the appendix, Figure A.1 shows graphically a negative relation between property tax rate and the last year of cadastral revision. Figure A.2 shows how the distribution of municipalities with regard to their last cadastral revision is bimodal, with 2001 being the cut-off point of that distribution. Finally Table A.1, based on the foregoing information, shows that municipalities that last revised their cadastral values before 2001 have a property tax rate that is 0.26 points higher than those with cadastral values revised after 2001 .

13. The budgetary information for this municipality is not available.

14. Ideally, to construct this variable we would have needed detailed (real) data on the flow of commuters between municipalities, obtained from traffic and public transport statistics, or from mobility surveys. Given the impossibility to get such data for all the municipalities in our database we have opted to use population as a fairly credible proxy for "potencial" commuters and, hence, potential users of the (public) services offered in each considered municipality (see also Solé-Ollé and Viladecans, 2004). This geographical criterion was also considered in the Report on the big cities and the areas of urban influence, carried out by the Spanish Ministry of Public Administrations back in 2001; more precisely, the Ministry used a 35-km distance. Therefore, we have performed some robustness estimations defining the distance threshold to each municipality equal to $25-\mathrm{km}$ and $35-\mathrm{km}$. The obtained results, not reported but available upon request, do not change the main idea regarding this variable explained in the results section.

15. Again, we make us of the Report on the big cities and the areas of urban influence, carried out by the Spanish Ministry of Public Administrations in 2001 to define what it is considered a central city.

16. The rationale behind the variable $w_{-}$cost comes from the fact that salaries paid to public servants in large municipalities are, in general, higher than in smaller ones. In Spain each municipality has its own salary grid (especially affecting the so-called "specific complement"). Moreover, there are also some extra benefits (such as the productivity pay) for public servants that can widely differ across municipalities. The same is also true for politicians and public managers (not public servants but positions of truth) working for local governments.

17. The number of workers in the local administration in each municipality is calculated as follows; first, the number of local administration workers as a percentage of all public workers is obtained from provincial data; second, this percentage is then applied over the total number of public workers at the municipal level.

18. In the estimations presented in section 5, we opt to introduce both variables ( $w$ cost and employ_public) in some regressions in spite of their having a high correlation coefficient $(0.8)$, since we consider each to capture different aspects of capital costs - one the possible salary differentials between cities, and the other the presence of other administrations in the municipality.

19. As a robustness exercise we also use the ratio between the population under 19 years of age and the total population of the municipality (pop_under_19). These results are fairly consistent with those presented in section 5 . 
20. Current transfers are general grants basically from the central government, which try to account for the municipal differences in necessity, capacity and fiscal effort. The differences in needs are measured by the population weighted by increasing weights according to municipal size. However, these transfers are not granted to explicitly cover the enumerated extra costs of central and capital municipalities.

21. In the estimates of the determinants of the fiscal capacity we do not include property tax revenues in the calculation of own_taxes/pop.

22. Given that the economic interpretation of the estimated coefficients for these variables is difficult in relation to fiscal capacity, we also construct the variable pop_20_64. This indicates the share of the population aged between 20 and 64, and so serves as a proxy of the municipality's active population.

23. Given the nature of the underlying data, the quantitative interpretation of the obtained elasticities must be cautions, for instance, the use of complex indexes (such as the one used to approximate tourism) may complicate the interpretation of results at face value.

24. This statistically significant result would seem to reflect the fact that municipalities in Spain are, by large, key providers of children's services, including daycare, which while not obligatory competences are in great demand from local residents.

\section{References}

Allers, M. A. and Ishemoi, L. J. (2011), "Equalising spending needs of subnational governments in a developing country: the case of Tanzania", Environment and Planning C: Government and Policy, 29: 487-501.

Bailey, S. J. (2005), "Equalisation of municipal input costs in England: matters of «principle and practice»”, Environment and Planning C: Government and Policy, 23: 85-100.

Ball, R.; King, D. and Eiser, D. (2012), “Assessing the relative health care spending needs of the UK's devolved territories: a Scottish perspective", Environment and Planning C: Government and Policy, 30: 322-346.

Bosch, N. and Solé-Ollé, A. (2005), "On the relationship between authority size and the costs of providing local services: lessons for the design of intergovernmental transfers in Spain", Public Finance Review, 33: 343-384.

Brueckner, J. K.; Thisse, J. F. and Zenon, Y. (1999), "Why is central Paris rich and downtown Detroit poor?: An amenity-based theory", European Economic Review, 43: 91-107.

Cadaval, M. (2004), "Las aglomeraciones urbanas desde la perspectiva de la hacienda pública" WP19/04, Instituto de Estudios Fiscales, Madrid.

Chernick, H. and Tkacheva, O. (2002), "The Commuter Tax and the Fiscal Cost of Commuters in New York City”, State Tax Notes, 25: 451-456.

Glaeser, E. L.; Kolko, J. and Saiz, A. (2001), "Consumer City”, Journal of Economic Geography, 1: 27-50.

Greene, K. V.; Neenan, W. B. and Scott, C. D. (1974), Fiscal interactions in a metropolitan area, Lexington Books, Lexington.

Hawkins, R. and Murray, M. (2004), "Explaining interjurisdictional variations in local sales tax yield", Public Finance Review, 32: 82-104. 
King, D.; Pashey, M. and Ball, R. (2004), “An English assessment of Scotland's education spending needs", Fiscal Studies, 25: 439-466.

Ladd, H. F. and Bradbury, K. L. (1988), "City taxes and property tax bases", National Tax Journal, 41: 503-523.

Ladd, H. F. and Yinger, J. (1989), American Ailing Cities, Fiscal Health and the Design of Urban Policy, The Johns Hopkins University Press, Baltimore and London.

Ministerio de Administraciones Públicas (2001), Informe sobre las grandes ciudades y las áreas de influencia urbana. http://www.map.es

McLean, I. and McMillan, A. (2003), "The distribution of public expenditure across the UK regions", Fiscal Studies, 24: 45-71.

Midwinter, A. (2002), "Territorial resource allocation in the UK: a rejoinder on needs assessment", Regional Studies, 36: 563-567.

Solé-Ollé, A. (2001), "Determinantes del gasto público local: ¿necesidades de gasto o capacidad fiscal?", Revista de Economía Aplicada, 25: 115-156.

Solé-Ollé, A. (2006), "Expenditure spillovers and fiscal interactions: empirical evidence from local governments in Spain”, Journal of Urban Economics, 59: 32-53.

Solé-Ollé, A. and Viladecans, E. (2004), "Central cities as engines of metropolitan area growth, Journal of Regional Science, 44: 321-350.

\section{Resumen}

En este artículo determinamos los costes y beneficios de ser una capital o un municipio central, donde los costes en que se incurrirá se entienden específicamente como resultado de los problemas que experimentan los grandes municipios ubicados en el centro de una aglomeración urbana (incluyendo los costes asociados a los problemas sociales, la inmigración, la movilidad y las deseconomías de escala) y los costes de capitalidad son el resultado de la presencia de las instituciones de los gobiernos autonómicos y/o centrales en el municipio (pérdida de ingresos o aumento de los gastos debido a la sustitución de la actividad). Sin embargo, estas dos características también podrían ser beneficiosas para los municipios (como resultado de un aumento directo en sus ingresos o capacidad fiscal). Mediante la estimación de una ecuación de las necesidades de gasto y de la capacidad fiscal de los municipios españoles de más de 75.000 habitantes, se constata que los costes de centralidad incurridos por los grandes municipios se ven compensados por su mayor capacidad fiscal, pero que lo mismo no es cierto para los municipios que son capitales administrativas o políticas.

Palabras clave: financiación local, grandes municipios, costes y beneficios de centralidad y de capitalidad, necesidades de gasto, capacidad fiscal.

Clasificación JEL: H72, H77, R51. 
